\title{
Os Mortos Não Pesam Todos o Mesmo. UMA REFLEXÃO SOBRE ATRIBUIÇÃO DE IDENTIDADE POLÍTICA Às OSSADAS DA VALA DE PERUS
}

\author{
The Deceased Don't All Weight The Same. \\ A reflection on the political identification of bones \\ from the Perus mass grave
}

\author{
Desirée de Lemos Azevedo* \\ Universidade Federal de São Paulo (Brasil)
}

\begin{abstract}
Palabras clave
Desaparecimento Identificação Violência política Direitos humanos tados, argumento que o objetivo da identificação é escrutinar o conjunto ósseo para dele destacar alguns corpos aos quais serão atribuídos identidade política. Discuto três aspectos do processo: a humanização dos remanescentes a partir de seu tratamento científico; a identificação como um processo classificatório; e a materialidade como geradora de verdades científicas relacionadas a processos de formação do Estado Nacional e de gestão de populações.
\end{abstract}

RESUMO: Em 2014, foi criado no Brasil o Grupo de Trabalho Perus (GTP), uma equipe forense multidisciplinar dedicada à identificação dos remanescentes ósseos exumados, em 1990, da Vala de Perus. Por este nome, ficou conhecida a sepultura coletiva clandestina localizada no Cemitério Municipal Dom Bosco, no bairro de Perus, em São Paulo. Descoberta no final dos anos 1970, ela é a mais importante das valas comuns denunciadas como destino final de militantes desaparecidos pela Ditadura (1964-1985). É também a única a receber atenção científica e institucional. A partir de pesquisa etnográfica realizada junto ao GTP, este artigo analisa o processo de identificação posto em curso pela equipe, decompondo suas etapas, procedimentos, práticas e documentos. A partir dos dados apresen-

ABSTRACT: In 2014, the Perus Working Group, a multidisciplinary team of forensic experts, was created in Brazil to identify the human remains exhumed in 1990 from the Perus Grave. By this name came to be known a clandestine mass grave in the Dom Bosco Municipal Cemetery, in Perus district, São Paulo. The Perus Grave was discovered in the late 1970s and still is the most important mass grave reported as the final destination of activists victims of forced disappearance during the Dictatorship (1964-1985). It is also the only one to have received institutional and scientific attention. Drawing from ethnographic research,

\section{Keywords}

Disappearance Identification Political violence Human rights this paper analyzes the GTP identification process, decomposing its stages, procedures, practices, and documents. I argue that the overall purpose of the process is to scrutinize the ensemble in order to select the remains that will be taken as political ones. I discuss three aspects of the process: the scientific treatment of the remains as humanization; the identification as a classification process; and the relation between the scientific fact production and the State Building and Nation Building process.

\footnotetext{
* Correspondencia a / Correspondence to: Desirée de Lemos Azevedo. Universidade Federal de São Paulo (Brasil). Estrada do Caminho Velho, n. ${ }^{0} 333$ - Jd. Nova Cidade - Guarulhos - SP - CEP: 07252-312 - desireelazevedo@gmail.com - http://orcid.org/0000-0002-0266-6258.

Cómo citar / How to cite: De Lemos Azevedo, Desirée (2019). "Os Mortos Não Pesam Todos o Mesmo. Uma reflexão sobre atribuição de identidade política às ossadas da Vala de Perus»; Papeles del CEIC, vol. 2019/2, papel 218, 1-20. (http://dx.doi.org/10.1387/pceic.20389).
}

Recibido: noviembre, 2018; aceptado: febrero, 2019

ISSN 1695-6494 / CC 2019 UPV/EHU 
São Paulo, 04 de setembro de 1990. Autoridades estaduais e municipais, ex-presos e familiares de mortos e desaparecidos durante a Ditadura (1964-1985), representantes da imprensa nacional e internacional e populares estão reunidos no Cemitério Municipal Dom Bosco, no bairro de Perus. Sob as lentes das câmeras de TV e os flashes dos fotógrafos, a pequena multidão acompanha a abertura de uma vala comum, onde estão reinumados mais de mil remanescentes humanos, exumados de covas individuais do próprio cemitério em meados dos anos 1970. Comum no Serviço Funerário Municipal, o procedimento não justificaria tamanha atenção, não fosse o fato de que aquela era uma vala clandestina. Conhecida apenas por funcionários mais antigos que vinham guardando em segredo sua existência e localização.

Os acontecimentos desse dia tornariam a Vala de Perus mundialmente conhecida, rompendo os muitos silêncios que a envolviam. De destino coletivo de corpos «indigentes», abrigo da irrelevância das mortes não reclamadas, a vala passava a espaço de denúncia do assassinato de sujeitos que vinham sendo reivindicados como desaparecidos políticos desde a Ditadura. Buscando por eles, familiares e companheiros de militância política chegaram ao cemitério, ainda nos anos finais do regime, onde ouviram confidências de um funcionário sobre a existência de uma vala comum sem registro oficial. Mais de uma década depois, a exumação viria como conquista do movimento de familiares de mortos e desaparecidos políticos. Articulação nascida da coletivização dessas buscas entre as famílias e sua transformação em uma luta política por imprimir nova dinâmica ao tratamento até então dispensado às violências cometidas pelo Estado naquele período.

Uma vez exumados, os corpos adquiriam condição de evidências materiais de suas denúncias, forçando instituições do Estado a reconhecer, pela primeira vez desde a abertura política, direitos e responsabilidades decorrentes daquelas violências. Duas ações mais imediatas foram realizadas: uma Comissão Parlamentar de Inquérito na Câmara de Vereadores, e um convênio com a Universidade Estadual de Campinas (Unicamp) para a identificação.

A primeira iniciativa revelou a participação do Serviço Funerário Municipal e do Instituto Médico Legal (IML) no desaparecimento de pessoas assassinadas pelos órgãos repressivos, localizando testemunhas e importantes documentos referentes ao encaminhamento de seus corpos a Perus via burocracia funerária. A produção de uma narrativa sobre a Vala de Perus como dispositivo criado para ocultar desaparecidos políticos foi fundamental para a consolidação política e social dessa categoria, cinco anos depois institucionalizada por lei federal de caráter civil reparatório (Lei N. ${ }^{\circ}$ 9.140/95). A segunda iniciativa rendeu algumas identificações, mas logo foi abandonada. Após 24 anos, foi criado o Grupo de Trabalho Perus (GTP) para retomar e finalizar o trabalho.

Em 2014, instalada no laboratório do Centro de Antropologia e Arqueologia Forense da Universidade Federal de São Paulo (CAAF/Unifesp), a equipe forense recebeu a custódia de 1047 caixas plásticas com remanescentes ósseos, para os quais desenvolveu protocolos e procedimentos de análise. A partir de pesquisa etnográfica realizada junto ao GTP ${ }^{1}$ este artigo irá decompor e descrever tal processo de identificação em suas etapas. Na primeira parte do texto, o situo entre as técnicas de identificação civil do Estado brasileiro, nossas políticas reparatórias e o humanitarismo internacional. Entre a segunda e a quinta partes, aden-

\footnotetext{
Pesquisa iniciada em fevereiro de 2017, no âmbito do pós-doutoramento realizado junto ao PPGCS/Unifesp, com financiamento Fapesp. Agradeço à Marina Di Giusto, Isabela Mayá, Talita Máximo, Camila Souza, Lorrane Campos, Roxana Enriquez, Cynthia Sarti, Fabiana de Andrade e aos pareceristas de Papeles del Ceic pelas valiosas contribuições. O título do artigo é extraído de passagem de A longa Viagem, de Jorge Semprún.
} 
tro o laboratório e mergulho nas etapas propriamente ditas, procurando destrinchar os procedimentos e as maneiras pelas quais tomam a materialidade dos corpos como espaço de enunciação de verdades. Nas três últimas, argumento que a identificação só pode ser pensada como construção que se expressa na complexa rede de relações na qual os mortos se inserem com o Estado, o fazer científico e os familiares, na medida em que se constitui como tecnologia de governo.

\section{IDENTIFICAÇÃO CIVIL E HUMANITARISMO FORENSE}

«Identificar é individualizar aquilo que foi totalizado, devolvendo nome, história e dignidade.»

Com estas palavras, Rebeca, odontóloga forense do Comitê Internacional da Cruz VermeIha (CICV), concluiu sua apresentação sobre identificação de pessoas. Com o auxílio do power point, ela exibia casos de seus mais de vinte anos de prática forense, sustentando o argumento de que a identificação é um fenômeno de duas faces: de um lado um desaparecido, de outro um corpo não identificado. Um nome sem corpo e um corpo sem nome. Quem busca o primeiro pergunta: onde está? Quem se encontra diante do segundo: quem ele era? Identificar é reconciliar nome e corpo através da comparação entre informações produzidas a partir de diferentes metodologias científicas sobre um e sobre outro, chegando a um resultado interdisciplinar. É um processo técnico, objetivo e interpretativo, cujo sucesso está vinculado à qualidade dos profissionais envolvidos².

A oportunidade de ouvir Rebeca me foi dada em uma manhã em fevereiro de 2017. Em minha segunda visita ao CAAF, tive a sorte de acompanhar a equipe em uma de suas iniciativas de diálogo com atores internacionais experientes na identificação de vítimas de violações de Direitos Humanos. Durante sua fala, Rebeca referia-se a técnicas forenses desenvolvidas em atenção a vítimas de violência em contextos críticos, muitos deles marcados pelo fenômeno do desaparecimento forçado, e que tomam como base padrões globalizados de intervenção humanitária. Tipificado internacionalmente, tal fenômeno é caracterizado por sua relação com violência decorrente de instabilidade política e social, permitindo aplicação a uma variedade de contextos em que se observam atípicos desaparecimentos de pessoas e/ou, seu contraponto, o aparecimento de ossadas/cadáveres desconhecidos. É diante da emergência coletiva destes últimos, que Rebeca fala da identificação como individualização daquilo que foi totalizado.

O processo de identificação no GTP define-se por estes mesmos pressupostos. De um lado, a equipe está diante de um conjunto de mais de 1.000 ossadas sem nome. De outro, se insere na trama institucional criada em torno à figura jurídica dos mortos e desaparecidos políticos que, na conta do reconhecimento oficial, são 434 pessoas em todo o país ${ }^{3}$. Na intenção de re-

2 Os nomes dos profissionais citados são pseudônimos.

3 Seu o objetivo é a «identificação de mortos e desaparecidos políticos assim reconhecidos pela Lei $n .^{\circ} 9.140 / 95$ » (p. 2), segundo o Acordo de Cooperação Técnica N. ${ }^{\circ} 001 / 2014$ celebrado entre: a então Secretaria de Direitos Humanos da Presidência da República, a qual se vincula a Comissão Especial sobre Mortos e Desaparecidos Políticos (CEMDP) criada pela Lei 9.140/95; a Secretaria Municipal de Direitos Humanos e Cidadania da Prefeitura de São Paulo, que custodia as ossadas; e a Universidade Federal de São Paulo (Unifesp), que estruturou o Centro de Antropologia e Arqueologia Forense. Outras instituições do Estado estão representadas no Comitê Científico e Comitê de Acompanhamento. Neste último também há familiares. 
lacionar aqueles corpos com estes nomes, o GTP ouve e compara o que têm a dizer os ossos, as famílias, e os documentos. Nos termos mobilizados naquela mesma manhã por Sérgio, geneticista forense da polícia brasileira, o GTP trabalha com base em «processos científicos de identificação humana», comparando informações ante mortem e post mortem, produzidas segundo protocolos elaborados em articulações institucionais e consultoria internacional, asseguradas por cadeia de custódia e extensa documentação.

Apesar de atuarem em instituições com natureza, escala e objetivos distintos, desde especialidades diferentes, Rebeca e Sérgio são profissionais que exercem atividades voltadas à chamada identificação humana. O diálogo entre eles, mesmo atravessado pela maneira como as mencionadas diferenças os posicionam no campo forense ${ }^{4}$, flui pela compreensão comum de que a identificação é um processo em que a aferição de dados inerentes à materialidade dos corpos permite a constatação da realidade de suas identidades. A presente reflexão se distancia dessa posição. Ao destacar pressupostos e relações sociais subjacentes aos processos que conformam a identificação, argumento em favor de seu caráter mais criativo do que propriamente verificador.

Entre as reflexões que me informam, a de Letícia Ferreira (2007), sobre a designação de corpos como não-identificados no Instituto Médico Legal do Rio de Janeiro, entre as décadas de 1940 e 1960, é a mais inspiradora e inquietante comparativamente. Em sua pesquisa, a autora fala de corpos que aparentemente passaram pelo processo inverso ao que pretendo analisar. Corpos que, após darem entrada na instituição, sujeitados ao escrutino de especialistas em uma sequência prevista de procedimentos, de lá saíram como desconhecidos. Um fato intrigante se considerarmos a lógica que intui o cadáver exposto ao exame como espaço próprio à enunciação de verdades. Essa aparente incongruência permite questionar: o que é um corpo não-identificado? Do que decorre e no que implica sua existência? Ao perseguir estas e outras questões, Ferreira apresenta proposições que ajudam a pensar a identificação no GTP (ibidem). Razão pela qual inicio a discussão refletindo com a autora e parte da bibliografia que mobiliza.

Remontando à genealogia do método clínico de Foucault (1980), Ferreira lembra como a dissecação de cadáveres para estudos de anatomia e patologia marcou um ponto de inflexão metodológica com implicações profundas sobre o campo médico e além (ibidem). A partir dele, o corpo morto foi tornado espaço discursivo, permitindo o pronunciamento sobre fatos concretos da vida física do corpo, sua individualidade, doenças e morte. É porque os saberes e as práticas mobilizados para produzir esses conhecimentos revelam possibilidades de servir à gestão da vida em sociedade que eles adentram a dimensão legal, informando técnicas forenses institucionalizadas em órgãos da administração do Estado.

No Brasil, a identificação firmou-se como fazer policial. Conforme mostra Carrara (1984), uma "ciência e doutrina da identificação" surgiu da estreita relação estabelecida entre um discurso sobre a identidade individual como fato biológico passivel de ser objetivamente auferido e a construção de tecnologias de governo. Datando do século XIX, tal estreitamento refletia um movimento de penetração da Medicina no campo do Direito, particularmente na área penal, onde a figura perturbadora do criminoso começava a encontrar explicação na ideia de constituição biologicamente anômala. Qualificação construída pela Medicina Legal

4 Pensando campo com Bourdieu (2011: 50) como sistema relacional de agentes e instituições que se voltam direta ou indiretamente para um fazer, se defrontando segundo interesses específicos e as posições relativas ocupadas. 
na própria medida em que se institucionalizava como campo do saber e fazer profissional especializado.

Segundo Carrara (ibidem), a crescente crença nos fatores patológicos da criminalidade ganhava força, levando a uma aposta na prevenção e regeneração que se refletia na medicalização da polícia e da justiça. Característica comum às modernas sociedades disciplinares, nas quais a vida como corpo biológico se tornava objeto da racionalidade governamental (Foucault, 1999). Como bem nota o autor, por um lado, tal ideologia levava à classificação por categorias patológicas dos cidadãos e grupos sociais considerados «desviantes», implicando em sua totalização; por outro lado, para lhe dar consequência, as técnicas deviam se prestar a olhares individualizados que permitissem identificá-los para atuar em sua regeneração. Surge assim o impeto de buscar na anatomia humana os traços distintivos de criminosos, cujos comportamentos desviantes deveriam ser alvo de intervenção.

Entre as técnicas desenvolvidas, o sistema datiloscópico, a partir da descoberta da singularidade das impressões digitais, alçou a identificação a outro patamar. Distinguir, a partir de uma característica física observável não apenas criminosos, mas todo cidadão foi, conforme ainda argumenta Carrara (1984), evento que a transpôs para aplicações civis, abrindo a possibilidade de imaginar uma nova ordem social organizada por um Estado apto a conhecer e classificar sua própria população. Dá-se, assim, o surgimento da identificação civil obrigatória sob a responsabilidade policial. Segundo o autor, o projeto de desenvolvimento de uma polícia científica é firmado, nesse contexto, sobre uma doutrina segundo a qual a representação da ameaça social estaria no «homem desconhecido». Sintetizador da percepção da sociedade como caos a ser organizado.

Condizente com o processo de urbanização vivido na primeira metade do século $x x$, a sociedade (ameaçada e ameaçadora) generaliza a suspeição sobre o anonimato diante das clivagens políticas e sociais que se aprofundam, procurando demarcar critérios mais claros de inclusão/exclusão na cidadania (Corrêa, 2013). Daí a aposta na identificação total da população pelo conhecimento e catalogação de suas individualidades propriamente biológicas para constituir o indivíduo como personalidade civil ao afastar o anonimato pelo sistema que atribuí à sua digital única um número de série também único (Carrara, 1984). Materializado pelo documento de identidade que, em nosso cotidiano, tanto afasta suspeitas, quanto garante direitos da cidadania, indexando toda uma carreira documental que cada personalidade civil constitui do nascimento até sua morte. Ao tornar-se o principal ordenador de deveres, responsabilidades, direitos, e bens, o documento de identidade concretiza o sucesso da identificação no Brasil como técnica de governo que, como bem lembrou Ferreira (2007), será exigida até mesmo aos mortos.

Como tarefa assumida pelo Instituto Médico Legal, a identificação foi incorporada aos procedimentos médicos e burocrático cartoriais levados adiante na instituição, como mostra Medeiros (2012), para transformar cadáveres em mortos. Isso é, em individualidades acessíveis ao Estado através de sua linguagem documental. A necrodatiloscopia e a antropologia (para as ossadas) nomeiam dois departamentos do IML (ibidem) onde técnicas homônimas são mobilizadas para gerar documentação em torno ao cadáver, constituindo assim sua morte. Caso não possa ser associada a uma personalidade civil constituída (a identificação por nome próprio), tais técnicas permitem produzir um eu civil post mortem, inscrevendo da mesma maneira a individualidade empírica examinada nos mecanismos da racionalidade burocrática como um corpo não-identificado (Ferreira, 2007). 
Os não-identificados nos interessam porque desconcertam as proposições de Rebeca e Sérgio, já que tal categoria não é uma constatação da realidade de suas individualidades. Isto é, não existe algo como corpos "essencialmente destituídos de identidade» (ibidem: 2). Assim, o fato de corpos serem efetivamente enterrados com essa designação sugere que uprocessos científicos de identificação humana» também se prestam à totalização. Conforme bem argumenta a autora, se no decurso do processo ao qual são submetidos os corpos no IML um conjunto específico é destacado e nomeado a partir desse denominador genérico comum, isso que poderia ser chamado de uma não-identificação implica igualmente na construção e atribuição de uma identidade. Ou seja, uma identificação. Daí que o processo seja definido como criador, uma vez que apresenta capacidade de produzir realidade ao categorizar.

Tal reflexão ilumina os procedimentos que eu pude observar na identificação das ossadas de Perus, conforme detalharei nas próximas seções. Os processos desencadeados pela equipe compartilham com os realizados no IML mais do que certas técnicas, práticas e profissionais forenses. Igualmente assentada na visão da materialidade como reveladora de verdades, a identificação no GTP não prescinde de totalização. Ao contrário, seus procedimentos lidam com uma forma de individualizar que passa pela inserção em categorias. Identidades coletivas existentes apenas na medida em que são atribuídas. A comparação sugere que, em ambos os casos, estamos diante de processos classificatórios que apresentam menos relação com a materialidade dos corpos do que com a importância conferida aos mortos em sua existência simbólica (Verderey, 1999). Importância definida na dinâmica entre as relações interpessoais e o luto e a disposição estatal de governar (e se produzir governando) a transição entre e a vida e a morte (Stepputat, 2014).

Historicamente, essa dinâmica ampara a documentação de corpos como não-identificados pelo IML e seu envio ao setor dos cemitérios destinados ao enterramento por órgãos públicos. Nestes setores, exumações são obrigatoriamente feitas para dar lugar a novos sepultamentos. Os ossos são enviados para ossários (valas comuns) ${ }^{5}$, onde a indistinção é rapidamente alcançada, concretizando sua totalização categórica prévia. Ao mostrar a existência de um caminho traçado pela racionalidade burocrática até o sepultamento anônimo e coletivo, Ferreira (2007) destrincha também a lógica impressa no trabalho médico cartorial que converge características como: descuido material, economia de esforços, e generalidade no apontamento de informações. Elas assentam a banalidade de corpos não reivindicados, cujas mortes são tratadas como ordinárias e recebem o carimbo genérico, embora não oficial, da «indigência». Marca levada por terem sido deixadas a cargo do poder público. O que a autora consegue nos mostrar é que assumir tal encargo não é um recurso meramente assistencial, mas uma forma do Estado ordenar a vida social segundo sua racionalidade e policiar o espaço público, movendo esforços apenas suficientes para remover estes corpos indesejados e torná-los acessíveis a sua linguagem burocrática que, baseada em um modelo de vida fixa e envolta em laços duradouros, deixa restar inúmeros desviantes (ibidem).

Em conjunto, os citados trabalhos de Ferreira (2007), Carrara (1984) e Corrêa (2013) mostram o quanto as técnicas de identificação, desenvolvidas no âmbito de uma Medicina Legal informada pela necessidade de governar corpos (vivos e mortos) e controlar ameaças à ordem so-

\footnotetext{
5 As legislações funerárias municipais estabelecem tempos para este procedimento administrativo. A de São Paulo define-as como compulsórias para «indigentes», pessoas falecidas em hospitais, enfermarias, prisões ou remetidos pela polícia, e válidas para sepulturas privadas, quando não renovada a concessão.
} 
cial, são parte dos mecanismos estatais que governam distribuindo desigualmente a precariedade (Butler, 2017). Pensar o não-identificado e a vala comum como lugares (categórico e de fato) historicamente destinados às vidas precárias - o escravo, o liberto, o índio, o vadio, o mendigo, o pobre, o favelado, o marginal, o criminoso, o louco, a prostituta, o natimorto, o feto abortado- levanta questionamentos sobre as razões que levaram a Ditadura a ter utilizado preferencialmente os caminhos do IML e dos cemitérios públicos para desaparecer os corpos de seus inimigos políticos assassinados. Inserindo a "subversão" entre as ameaças estabelecidas nessa relação dialética entre anonimato e identificação ${ }^{6}$. Observar os caminhos burocráticos que levaram os militantes à vala comum pressupõem admitir que ela já estava presente no destino de outros indesejados. Perspectiva com potencial para embaralhar certezas sobre o que se entende por desaparecimento político no Brasil. Mas que, ao contrário, se fixam nas clivagens que o GTP reafirma ao observar, quando assenta seu fazer nas linhas dadas por uma legislação reparatória exclusivamente direcionada à «violência política».

Chave para a compreensão do passado ditatorial, "violência política» é a categoria que sustenta, permitindo que convivam, tanto a Lei de Anistia ${ }^{7}$, quanto as políticas reparatórias construídas, a partir dos anos 1990, como resultado da pressão exercida pelas memórias e lutas por direitos protagonizadas pelos opositores sobreviventes. Segundo o relatório Brasil Nunca Mais (1985), o perfil da oposição vitimada era masculino, jovem, urbano, branco e proveniente das classes médias.

O movimento de familiares foi o responsável por descobrir que muitos desses militantes buscados como desaparecidos haviam sido sepultados como «indigentes», com mortes documentadas por laudos e atestados de óbito. A Vala de Perus pesou significativamente para que seus reclames rompessem interdições comumente atribuídas à Anistia, abrindo uma era de reconhecimentos. Marcada, contudo, por uma timidez reativa às movimentações destes grupos. Como fenômeno histórico e legal, o desaparecimento político restou circunscrito às vítimas buscadas pelos movimentos sociais: os militantes políticos. Em uma dinâmica que veio a correlacionar estreitamente o fenômeno social a um tipo social de vítima. $O$ que é o desaparecimento político a quem são os desaparecidos políticos. Pois esbarrou no limite das forças, das redes e da imaginação social do movimento de familiares que, ao investigar e construir um a um, com evidências documentais e testemunhais, os casos que lhes garantiriam direitos individuais, também demarcaram a violência que nós seríamos capazes de nomear como sociedade contra uma persistente negação estatal (Azevedo, 2018) ${ }^{8}$.

Contudo, a Ditadura fez da violência uma prática social extensiva, operada largamente no espaço entre a legalidade e a disciplinação dos corpos (Das e Poole, 2004). Por isso, a categoria

6 Refiro-me ao fato de que a identificação é técnica que tanto tenta evitar o anonimato de tipos sociais ameaçadores, quanto permite sepultá-los anonimamente.

7 A abertura política é marcada pela Lei de Anistia (1979) que, em um primeiro momento, silenciou o debate ao perdoar «crimes políticos e conexos». Incluindo neles tanto as ações de grupos de resistência, quanto a violência de Estado.

8 Iniciado pelos mortos e desaparecidos políticos, o reconhecimento surgiu restrito às dimensões civil e individual do dano. Perspectiva não modificada o suficiente para que nosso processo não seja dito incompleto e atrasado quando interpelado pelo pacote transicional global. Contudo, como argumenta Castillejo Cuéllar (2018), talvez a inadequação esteja na própria imaginação desse contexto ideal e controlado de ruptura no qual, sob a promessa de novo futuro, seria possivel confinar a violência no passado. Tanto mais se considerarmos os limites à compreensão do que se constitui como violência em sociedades rasgadas por desigualdades sociais profundas que, historicamente, estruturam o cotidiano e enraízam tecnologias de governo, conformando a normalidade do funcionamento da sociedade e das instituições. 
"violência política» carrega clivagens sociais. Ela contém desigualdades ao excluir a possibilidade de reconhecimento para pessoas vitimadas em função de outros processos normalizadores desencadeados em nome de coisas como: a ordem pública, o desenvolvimento, ou a moralidade. Ou mesmo por defenderem: direitos sociais, diversidade cultural, modos de vida, ou territórios. Enquanto as violências contra as vidas destas populações historicamente marcadas pela precariedade são relegadas à ordem cotidiana, voltaram-se extraordinárias aquelas significadas pelas narrativas sobre a resistência ventiladas por sobreviventes, partidos políticos e movimentos sociais com eles identificados. A condição de vítima pôde ser alcançada por atores que até a Ditadura eram admitidos nas arenas políticas, cujo banimento causa horror e indignação. A relevância atribuída a suas vidas por estes setores permitiu que suas mortes, dignas de luto, fossem colocadas no centro das memórias nacionais da violência e admitidas como ofensas à democracia e à humanidade por tecnologias de governo elaboradas em sua atenção.

Tais tecnologias respondem, simultaneamente, à inserção do país no compromisso humanitário internacional que marca a transição para o século xxı (Torpey, 2006). Permitindo que gramáticas e agendas globais fossem mobilizadas para elaborar categorias capazes de circunscrever e denunciar o caráter excepcional daquelas violências que se exigia serem desdobradas em problemas sociais. Apoiando-se nos amplos parâmetros e vasta aplicabilidade das categorias humanitárias. Conforme mostra Gatti (2017), o sucesso da tipificação internacional do desaparecimento forçado converteu o que era um fenômeno carente de explicação em uma "variável que explica» (ibidem: 27), possibilitando tanto dar vazão a demandas locais contra Estados violadores, quanto totalizar um fenômeno mundial, a despeito de suas conformações contextuais ${ }^{9}$. Como instrumento de governança global, o desaparecimento forçado sustenta políticas, projetos e organizações, além de mover pessoas, saberes e valores.

Um movimento que não pode ser separado da ação de equipes forenses que, atuando a partir dos anos 1980 em contextos transicionais, projetaram o corpo ao centro da ação humanitária, produzindo um impulso global por localizar, identificar e judicializar. A eficácia legal de sua discursividade científica vem promovendo seus profissionais a aliados preferenciais das famílias, em contraponto a órgãos oficiais nacionais perpetradores ou coniventes. Além de recuperar remanescentes, sua atuação celebra a materialidade como traço objetivo da realidade e evidência mais acurada do que os testemunhos, produzindo um giro forense no campo humanitário. A emergência desse paradigma no qual a materialidade assegura a produção da verdade, tornando-se veículo preferencial para medidas diversas, como: o processamento penal, a interpretação do passado, a promoção do luto e da memória, e a transformação do futuro, em uma perspectiva fortemente triunfalista (Anstett e Dreyfus, 2015).

Tantas atribuições dotam o humanitarismo forense de um impulso alquímico e emergencial (Moon, 2014), validando-o pelo que seria sua ampla capacidade de oferecer limites ao exercício do poder, sem nunca se confundir com ele. Criado no auge do discurso transicional no Brasil, durante o funcionamento da comissão da verdade, o GTP goza destes predicados. $\mathrm{O}$ amparo dado a ele pelo campo humanitário veio a equilibrar as desconfianças que o movi-

9 As convenções internacionais o definem como privação de liberdade, perpetrada pelo Estado ou com sua conivência, seguida da recusa em admitir e informar o paradeiro. O desaparecimento político difere dessa formulação por ser uma categoria de direito civil, restrita a um período e tipo de vítima, e por igualar o desaparecimento à morte (Azevedo, 2018). 
mento de familiares mantém em relação o Estado ${ }^{10}$. Assim como a confiança na capacidade das técnicas científicas de extrair as verdades guardadas pelos ossos ameniza a emergência de um protagonismo forense que, pela primeira vez, desloca o movimento da centralidade na lida com os desaparecidos, ao encerrá-los no laboratório. Mas esta perspectiva resistiria a um olhar aproximado?

Em face da normatização do humanitarismo forense como projeto global, pesquisas recentes vêm iluminando os modos diversos pelos quais a materialidade pode ser constituída como fato em distintos contextos. Considerando as múltiplas questões abertas e tramadas por seus dispositivos entre as dimensões profissional, científica, religiosa, política, legal, histórica, afetiva e ética (Dziuban, 2017; Rosenblatt, 2015). Elas também chamam atenção para as variadas maneiras pelas quais tais dispositivos são capazes de, a um só tempo, responder e impactar atores e dinâmicas locais. Pensando suas inscrições nas densas redes sociais e jogos políticos nos quais são mobilizados como parte constituinte dessa conformação mundial (Ferrándiz e Robben, 2017). Lidas na esteira das reflexões abertas por Verdery (1999), tais análises me sugerem que, ao buscar restabelecer remanescentes ósseos à condição de sujeitos diante de comunidades políticas, os mecanismos forenses podem ser mais comuns do que sua proclamada excepcionalidade anuncia (Lefranc, 2017).

O mesmo parece se passar com o GTP, cujos processos científicos não podem ser apartados dos regimes burocráticos e de poder que instauram a identificação humanitária como uma tecnologia de governo. Assim como na identificação civil, a humanitária visa (re)estabelecer vínculos entre individualidades biológicas e o Estado, projetando representações sobre o anonimato e agentes políticos ameaçadores. Ao trabalhar com o princípio de que diferença biológica original faz indivíduos perante a lei e a burocracia, os teóricos da identificação civil brasileira implantaram técnicas capazes de classificar indivíduos segundo ordens específicas e hierarquias convenientes ao governo de populações (Foucault, 2007). Conforme mostrarei nas próximas seções, tal argumentação pode ser transposta para o GTP, cujos procedimentos buscam nos corpos diferenças originadas em desigualdades sociais sobre as quais projetam «critérios diferencias de acesso à cidadania» (Carrara, 1984: 15). Para entender como isso ocorre, precisamos entrar no laboratório.

\section{O LABORATÓRIO}

O CAAF/Unifesp ocupa um imóvel de dois pavimentos em rua residencial no bairro da Vila Mariana, na cidade de São Paulo. No subsolo, duas salas climatizadas acondicionam as 1047 caixas contendo os remanescentes ósseos exumados da Vala de Perus, uma terceira sala serve à secagem e, no espaço entre as três, ocorre a Limpeza.

As caixas estão registradas por uma série codificada. Um sistema alfanumérico composto pela sigla GTP seguida da sequência numérica atribuída outrora pela Unicamp. Para cada có-

10 Enquanto a Equipo Argentino de Antropología Forense (EAAF), chamada pelo movimento de familiares, foi impedida de participar do processo no passado pela Unicamp, o GTP estabeleceu relações com três das mais importantes equipes forenses globais: a EAAF; a EPAF, Equipo Peruano, e o International Commission on Missing Persons; além do CICV. 
digo, uma pasta correspondente armazena os papéis gerados no decorrer da análise. Elas são guardadas em estantes de arquivo suspenso localizadas no andar térreo, acessado por uma escada interna.

Ao subi-la, chegamos em uma grande sala sem divisórias, cujas janelas, voltadas para o interior, conformam um vão central. Neste cômodo, as profissionais se distribuem entre três pias, quatro mesas de análise, uma bancada fotográfica, e cinco computadores. O único cômodo separado é provido de uma pequena pia, um freezer que atinge 80 graus negativos, e uma capela de exaustão. É a sala do DNA.

Os espaços constitutivos do laboratório do GTP são definidos pela circulação contínua das caixas e suas respectivas pastas. De tal maneira que, iniciado o percurso de análise, a dupla atravessa as etapas/estações de trabalho, como numa linha de produção. Ao passarem de etapa, abrem vez às que aguardam o momento de serem trabalhadas. Um observador que adentre o laboratório em um dia qualquer, verá caixas e pastas acumuladas sobre mesas e bancadas ao lado de peritas que executam seus trabalhos, simultaneamente, em distintas posições. Com o passar dos dias, estes conjuntos se dispersam, dando lugar ao acúmulo de outros ao ritmo de um trabalho que, colocando tudo em circulação permanente, parece manter-se estagnado.

Assim, para acompanhar o fluxo da análise, faz-se útil assumir o ponto de vista de uma caixa -a caixa GTP1234- e segui-la em seu itinerário laboratorial ${ }^{11}$. O que nos leva de volta ao subsolo.

\section{RESÍDUO E HUMANO}

Nos acompanham duas peritas: Tânia, responsável pela guarda das caixas, e Carolina, pela Limpeza. Como ato inaugural, a Cadeia de Custódia é transferida, abrindo a sequência de procedimentos e etapas, cuja validade, bem como a autenticidade de sua correspondência com a caixa, depende do registro datado de seu início e encerramento nesse documento, destinado ao controle do fluxo e encadeamento documental, assegurado pela autoridade investida nas assinaturas das peritas.

A esta abertura, segue-se a da caixa lacrada. Defronte às salas de acondicionamento, Carolina trabalha entre uma bancada fotográfica e um suporte de meio tambor sobre o qual posiciona uma peneira de aproximadamente $100 \times 60 \mathrm{~cm}$. Auxiliada pelo voluntário Pedro, ela traz consigo uma câmera digital; uma peneira extra; a pasta GTP1234 já com sua Cadeia de Custódia; uma escala; alguns códigos impressos em papel; e o Formulário de Limpeza.

11 O código é fictício. A descrição em sequência é recurso narrativo estruturado sobre dados etnográficos. Embora limitadas pelos protocolos, variações nas formas de trabalho acompanharam o revezamento entre equipes de peritas contratadas temporariamente por editais do Programa das Nações Unidas para o Desenvolvimento. O laboratório conta ainda com: voluntários, peritos cedidos pelo IML, Polícia Federal (PF), e Universidades. Representantes das instituições cooperantes compõem o Comitê Gestor. Representantes da Secretaria Nacional de Segurança Pública, da PF e da Associação Brasileira de Antropologia Forense estão no Comitê Científico. 
Enquanto Pedro fotografa a caixa -lacrada, aberta, com conteúdo à mostra e do lado de fora-, Carolina inicia o preenchimento do Formulário pelos dados de identificação. Ela seguirá nessa função, enquanto Pedro desembala o conteúdo, geralmente envolto em mais de um tipo de saco, íntegros e/ou fragmentados. Como camadas temporais, eles são vestígios materiais das subsequentes intervenções sofridas.

Carolina e Pedro trabalham em dupla conferência. Sobre a peneira, instrumento de seleção mecânica, os ossos e dentes íntegros são separados de resíduos como terra, insetos e pupas. É preciso atenção para visualizar ossos muito pequenos e os fragmentos com condições de serem reconstruídos, distinguindo-os de partes tão fragmentadas que também serão consideradas resíduos. Observação e registro são dois atos constitutivos do mesmo movimento: enquanto as partes ósseas vão sendo dispostas por conjuntos anatômicos na bancada e fotografadas por Pedro, ao lado da escala e do código, Carolina descreve detalhadamente todo o conteúdo ósseo encontrado, seu estado de conservação, e observações sobre eventuais cabelos, pelos e materiais de origem não-humana. Estes materiais, assim como etiquetas e outros objetos inseridos pela Unicamp, e as embalagens originais são armazenados. Afora os itens classificados como resíduos, nada é lixo. Curativos, pedaços de tecido, meias, dentaduras, e pedaços de embalagens de salgadinho são alguns dos objetos que vi serem arquivados na condição de evidências.

É também como evidências científicas que os ossos seguem adiante. Em nova peneira etiquetada, eles são levados ao andar superior, onde entram na fila da lavagem. Com pouca água e uma escova de dentes, um voluntário se dedica a remover, em paciente trabalho, consideráveis quantidades de terra dos ossos um a um. Limpos, eles descem à sala de secagem, de onde subirão quando completamente secos.

Acompanhar a Limpeza é observar uma transformação no decorrer da qual um amálgama disforme começa a assumir forma humana. Mesmo que, nesse momento, uma forma mais classificatória do que anatômica, pois é sua separação dos resíduos e a introdução de uma ordem (Douglas, 2010) que parecem restituir a qualidade humana da qual a matéria parecia esvaziada. Como se os processos sucessivos que a trouxeram até o GTP tivessem suspendido uma fronteira ontológica (Bevilagua, 2010), exigindo das técnicas de identificação uma atuação no sentido de restituí-la.

\section{OS OSSOS FALAM}

Secos os ossos, a peneira GTP1234 é levada para a Análise Antropológica. Recebendo a custódia de Carolina, Maíra, perita de análise post mortem, repassa o código à mesa e dispõe os ossos pela primeira vez em posição anatômica. Neste momento, observa ossos ausentes, sobressalentes, e morfologicamente incompativeis com o conjunto. Resultado de perdas e misturas ocorridas durante o histórico de circulação das ossadas. Algumas dessas incompatibilidades pareciam muito nítidas ao meu olhar leigo, como diferenças de tamanho, ausências e sobressalências; outras desafiam olhares treinados. Por isso, Maíra costuma buscar opiniões entre suas colegas. Prática comum, os debates entre peritas com distintas formações e experiências sobre os casos em análise são, tanto quanto os protocolos e manuais de padronização, investimentos no rigor. Controles de «desvios interpretativos», me explicou Maíra. 
Enraizada no paradigma indiciário (Ginzburg, 1989), a prática forense entende a si mesma como decifrar as pistas de um enigma. Comparação feita por uma prestigiada antropóloga forense portuguesa durante uma de suas visitas ao laboratório. É interessante que a inquietação com a subjetividade seja parte constituinte de um fazer que, informado pelos sentidos, centralmente a visão, volta-se para o corpo morto como espaço privilegiado para entender o que está além do visível. Mas Maíra também me explica que, para alcançá-lo, são necessários exercícios de abstração: classificações e formação de totalidades. A questão é que "um osso sozinho não me diz nada», explicou em certa ocasião. Na dimensão do visível, é difícil relacionar objetivamente dois ossos fora do conjunto esqueleto. Em sua montagem, como em um quebra-cabeças, é preciso seguir o modelo anatômico para dispô-los em suas posições, respeitando sequências e lateralidades, testar encaixes entre partes e articulações, e comparar os lados. É apenas na visão do todo que se pode ter certeza sobre o pertencimento das partes. Em alguns casos, como as costelas, chega a ser impossivel determinar a posição anatômica de algumas de maneira não relacional. No decorrer do procedimento, além de separar elementos estranhos ao conjunto, Maíra reconstrói e cola os ossos fragmentados. E quando finalmente concluí estar diante de um único corpo, testa se é possível associar entre si os ossos considerados externos. Em seguida, os demarca por um perímetro e fotografa a mesa ${ }^{12}$.

Encontramo-nos agora diante dos remanescentes de um inconfundivel corpo humano. Um esqueleto ainda que sempre incompleto ou fragmentado. As vezes faltam ossos como o crânio, fundamentais tanto para a análise, quanto para nossa concepção de pessoa. Em todo caso, sua individualização seguirá em curso. Maíra agora busca as informações solicitadas pelas Fichas de Análise Antropológica, compostas por: Inventário de Esqueleto, Perfil Biológico, Odontograma, Crânio: Vista (5 ângulos distintos), Esqueleto: Vista Anterior e Posterior, e Reporte Antropológico.

O Inventário de Esqueleto é uma relação minuciosamente discriminada. Todos os ossos de um esqueleto são apontados em uma tabela como presentes, ausentes, fragmentados ou incompletos. É avaliado seu estado de conservação geral, destacada a presença de outros materiais, e apontadas intervenções humanas ou efeitos naturais sobre os ossos. Mesma tarefa cumpre o Odontograma, que conta com uma tabela e uma representação gráfica a ser colorida para apontar presença ou ausência de cada um dos dentes, o momento da perda em relação à morte, e específicas informações individuais e posicionais. O Perfil Biológico se refere ao levantamento de dados para estimar: sexo, idade e estatura no momento da morte. Considerando que o dimorfismo sexual não é evidente em ossadas humanas, o protocolo prevê o uso complementar de três metodologias aplicadas a diferentes ossos do corpo. Maíra deve atribuir números de 1 a 5, em uma escala de graduação do «mais feminino" ao «mais masculino», para características observadas em 5 pontos do crânio, e três pontos da pelve. Depois, tira medidas do fêmur. Os números são lançados em fórmulas matemáticas calculando a probabilidade do sexo. Já a estimativa de idade é feita a partir de seis ossos diferentes, cujos resultados não são números precisos, mas faixas etárias, sobrepostas para alcançar a menor

12 Das 904 caixas analisadas até janeiro de 2019, 205 possuem ossos de mais de um indivíduo. O mais comum é encontrar algumas unidades não compatíveis com um indivíduo mais íntegro. Caso não seja possível lhes aplicar os métodos de análise, essas unidades serão chamadas «avulsas» em relação ao «indivíduo principal». Este fica referenciado no código. Quando é possível estimar seu perfil biológico, são considerados outro(s) indivíduo(s), classificados com o código mais letra (A, B, etc.). Considerando que indivíduos podem estar dispersos por várias caixas, ao final, seria necessário um esforço adicional para definir quantos indivíduos há no total nas 1.047 caixas. 
variação. O mesmo ocorre com a estatura, intervalo resultante de cálculos a partir da medição de 5 ossos.

As fichas Crânio: Vista e Esqueleto: Vista inauguram a análise das lesões e patologias. Coloridas em silhuetas, elas são descritas em seguida no Reporte Antropológico, um resumo geral discursivo do conjunto dos dados auferidos, com destaque para o perfil biológico, as características odontológicas e físicas individualizantes, a descrição das patologias e das lesões, e seu momento em relação à morte, como fatos médico-legais, apontando origem e causas. $A$ conclusão depende da articulação desse conjunto amplo de informações em direção à causa mais provável da morte de acordo com categorias médicas (Medeiros, 2012). Considerando que ela nem sempre é observável na ossada, não é incomum resultar indeterminada. O que também pode ocorrer com o perfil biológico. Para finalizar, Maíra vai à bancada fotográfica, onde captura as imagens das partes diagnósticas (perfil biológico, patologias e traumas), descrevendo tudo no Inventário Fotográfico. Toda essa extensa documentação é reunida à da etapa anterior na pasta. Os ossos são devolvidos à caixa, separados por conjuntos anatômicos em sacos tipo ziplock, com conteúdo descrito por fora.

O material devolvido à Tânia já não é o mesmo. O código GTP1234 designa uma materialidade transformada pela intervenção forense em um conjunto científico composto por: papéis, dados, imagens, e um esqueleto higienizado, escrutinado, ordenado e classificado. Apenas ao ser tomada como base para a emissão de verdades médicas em registros documentais é que a materialidade vem a constituir uma individualidade biológica. De conjunto ósseo indeterminado torna-se um esqueleto e, finalmente, um indivíduo morto: limpo, com sexo, idade, estatura, patologias, traumas e causa mortis estimados e documentados em linguagem médico-legal. Processo que o traduz para um universo aberto no encontro entre conhecimento e registro. Contudo, esse indivíduo segue como evidência de uma identidade, que não pode ser alcançada apenas por aquilo que se perscruta nos ossos.

\section{INDIVÍDUO E PESSOA}

Atribuir identidade, isto é estabelecer o dito elo entre corpo e nome, assim como na identificação civil, significa conectar uma individualidade física irredutível, no caso dos ossos localizada nos genes, a uma personalidade civil.

É nesse momento do processo que surge um ponto de inflexão. Se todas as caixas chegarão à Análise Antropológica, nem todos os indivíduos que dela emergem serão submetidos aos exames genéticos. Por restrições orçamentárias alheias ao processo científico, tais exames foram contratados para 750 amostras junto ao International Commission on Missing Persons (ICMP) ${ }^{13}$. Inferior ao total de individuos, essa quantidade exige selecionar aqueles que seguirão para as próximas etapas. Visando compor os lotes de amostras a serem enviados em subsequentes remessas internacionais.

13 Sem verba destinada à etapa, o GTP conta com recurso disponibilizado por emenda parlamentar da deputada federal Luíza Erundina. 
Por isso, ao receber de volta o conjunto, Tânia lança os dados de cada indivíduo codificado na planilha sobre a qual são aplicados os chamados Filtros Restritivos. Estas ferramentas de seleção são elaboradas a partir das características físicas das 41 pessoas que compõem o Universo de Busca. Tal Universo foi depurado dos 434 desaparecidos políticos que o Estado brasileiro tem obrigação de localizar e identificar. São 37 nomes selecionados como prováveis de estar na vala a partir das informações disponibilizadas pela documentação e testemunhos que fundamentam seus casos. Narrativas produzidas pelos familiares e apresentados à CEMDP para reconhecimento oficial. Os 37 nomes estão divididos em 6 distintos "graus» de probabilidade. Outros 4 nomes foram acrescentados por solicitações de suas famílias à Unicamp e mantidos pelo GTP.

Tal depuração e o levantamento das características físicas dos buscados foi feito pela equipe Ante Mortem junto às famílias e, para os casos existentes, à documentação produzida pela burocracia funerária acerca de suas mortes. Cada Filtro restritivo combina categorias referentes a sexo (ex: masculino), idade (ex: adulto jovem) e tipo de trauma (ex: lesão perimortem no crânio) associando os buscados em subconjuntos por semelhança física. A aplicação de cada Filtro respeita a ordem de prioridade definida pela divisão dos nomes entre seis diferentes "graus de probabilidade de estar na vala» ${ }^{14}$. Ademais, existem critérios de exclusão, na prática, mais determinante do que esta eleição por compatibilidade. Tais critérios determinam o encerramento da trajetória analítica de indivíduos estimados como: crianças, adolescentes e idosos, os com patologias graves, morfologias diferenciadas ou que sofreram cirurgias, por exemplo. Mesmo que apresentem lesões por trauma violento ${ }^{15}$.

De todos os procedimentos classificatórios descritos até aqui, e que restam ocultos sob a ideia de materialidade verificável, o Filtro é o mais explícito quanto à criatividade e o caráter classificatório do processo. Pois deixa claro que a primeira pergunta feita diante de um indivíduo não é "quem é», mas "se é um desaparecido político». Ao buscar tal resposta nas individualidades biológicas, o procedimento trata diferenças sociais por incompatibilidades físicas. A um só tempo, corporifica um conceito e cria corpos «essencialmente políticos».

Não é este o caso do indivíduo GTP1234. Razão pela qual será excluído nesse ponto do processo, sem alcançar a genética. Identificado pelo código, ele restará como personalidade post mortem diante do agente identificador. Legivel e descriminável por sua ordem de inscrição em uma totalidade sequer nomeada, mas sempre designada pela negativa na prática cotidiana. Do ponto de vista do processo - que mais do que nunca parece se opor pelo vértice ao descrito por Ferreira (2007) - também não se pode falar em não-resultado. Cada exclusão é um passo em direção a quem se busca em um processo que visa distribuir o corpus analítico entre dois conjuntos possíveis: os desaparecidos políticos e aqueles que não o são. Identificados por nomes próprios, os primeiros retornarão às suas famílias; enquanto o futuro dos que «não são» permanece, como eles, desconhecido.

14 Os graus são: 1. Pessoas com inumação e exumação registradas no livro do cemitério, sem informação sobre local de reinumação; 2. Inumação, exumação e reinumação registradas no livro; 3. Desaparecidos com informações de que passaram por órgão de repressão na cidade; 4. Desaparecidos na Grande São Paulo sem informações; 5 . Desaparecidos em outros locais, cuja busca foi solicitada por familiares; 6 . Desaparecidos não políticos solicitados por familiares.

15 Existem individuos nessa situação com indícios de execução. 
Para os indivíduos selecionados, o processo tem sequência na Revisão com um perito distinto. Se a Ficha de Revisão confirmar a análise, ocorre a transferência para o Corte. Etapa na qual Isadora, a perita da genética, corta duas amostras de um osso longo e extraí dois dentes, congelando-os até seu envio. Os lotes são compostos por uma amostra de cada tipo de cada indivíduo. No ICMP, elas serão comparadas com as amostras de referências de familiares dos buscados. Amostras de contraprova ficam reservadas no GTP, assim como as informações registradas na Ficha de Coleta de Amostras dos Restos Mortais para Exame Genético, e outro Inventário Fotográfico. O conjunto retorna, então, à Tânia na espera por resultados.

Após quase 5 anos de atuação, enviados três lotes no total de 550 amostras, o ICMP anunciou dois matches $^{16}$. Ambos os corpos seguiram para a Reconciliação, etapa em que, finalmente, foram diretamente comparados a um nome. Os indivíduos documentados pelas análises postmortem e genética são contrastados com Fichas Antemortem, também documentadas pelos papéis que constituem suas personalidades civis. Nos dois casos, houve confirmação na Ficha de Identificação, em que os peritos responsáveis se pronunciam sobre a autenticidade do vínculo entre corpo e nome, observando as dimensões Antemortem, Postmortem e Genética.

A referência no singular é, entretanto, imprecisa. Como evento que transborda o laboratório e a dimensão científica, a reconciliação se refere a múltiplos vínculos. Como bem argumenta Wagner (2008), identidade não é apenas um laço entre um corpo e um nome, mas também entre uma pessoa e um lugar, uma época e outros seres humanos. Nesse sentido, a reconciliação é mais do que uma identificação por nome próprio. Ela é também um ato de reconhecimento.

A reconciliação resulta no retorno a uma comunidade enlutada. Não de uma individualidade biológica, mas uma pessoa. Um corpo sobre o qual foi exercido um trabalho de instituição (Bourdieu, 2011) no decorrer do qual não houve propriamente uma verificação da verdade, mas sua instituição pela inscrição simultânea de uma tecnologia entre a ciência e o Estado, e de um corpo em um universo político e social concebido na distinção entre indivíduo e pessoa (Damatta, 1997). A identificação por nome próprio é o reconhecimento que reunifica as propriedades biológicas às políticas, sociais, jurídicas e morais. Produz pessoa na medida em que reconecta uma existência individual biológica a personalidade civil e sua carreira documental, que tanto conforma uma existência individual perante o controle estatal, quanto comporta propriedades morais e relacionais (Peirano, 2006). Daí que a identificação surja aqui, tal como no IML, como garantia exclusiva das mortes choradas. De vidas envoltas por laços duradouros, reivindicadas e consideradas em sua dimensão biográfica. Condição de diferenciação a partir da qual acessos distintos à cidadania são proporcionados para corpos que, na realidade material, saíram de uma mesma vala.

16 O exame de DNA é uma comparação entre sequências genéticas nas amostras testadas e de referência. Como não existe amostra de referência dos próprios indivíduos, a comparação é feita com a amostra de familiares. Por isso, é necessário calcular a probabilidade de haver coincidência sem que as amostras pertençam a parentes sanguíneos. Ou seja, a probabilidade de $X$ ser parente de $Y$ sobre a probabilidade de haver a mesma semeIhança sem parentesco. Quando há um universo de busca fechado, calcula-se a probabilidade a priori, usando a proporção 1 sobre o número de pessoas buscado. Depois, é preciso decidir o Umbral: a partir de qual probabilidade a posteriori, após o cálculo, aceita-se como match. 
Transpondo livremente os argumentos de Bourdieu em A ilusão biográfica (2006), tentar explicar a identificação de desaparecidos políticos como uma sucessão de procedimentos científicos sem outro vínculo senão a materialidade de seus corpos seria o mesmo que compreender sua trajetória como uma série de acontecimentos sucessivos sem outro vínculo que não a constância de um nome próprio.

Rebeca vê no nome a condição para atribuição de história e dignidade. Parece considerá-lo, tal como Bourdieu (ibidem), como princípio de irredutibilidade e estabilidade dos sujeitos, que unifica no tempo e espaço seus deslocamentos e possibilidades de manifestação como agentes no mundo social. Porém, como alerta o autor, o nome é também o rito de instituição inaugural. A constância que o permite encadear os acontecimentos de uma vida como trajetória -com sentido, projetos, relações e afetos- é a mesma sobre a qual se depositam os atestados jurídicos que articulam propriedades, benefícios e direitos e definem o cidadão perante o Estado. Se os nomes próprios designam individualidades inseridas em relações e processos, ao constituir de forma indissociável a categoria jurídica desaparecido político, eles demarcam as memórias e trajetórias que projetam sobre o espaço político nacional, qualificando sua relevância.

Assim, os nomes dos desaparecidos políticos carregam classificações e hierarquias como premissas das quais a análise forense não pode escapar. No passado, eles foram procurados pelo movimento de familiares nos livros de registro de entrada do cemitério. Revelaram então seis casos que haviam sido exumados administrativamente, mas não havia dados sobre suas reinumações. À época, os familiares entenderam que a vala clandestina foi o destino final desses seis corpos, mantendo aberta a possibilidade de que outros «políticos», que talvez entraram no cemitério como não-identificados, também pudessem estar ali.

Quando assumiu a tarefa de compreender a formação da vala e delimitar o Universo de Busca, a equipe Ante Mortem realizou um levantamento amplo junto ao livro do cemitério, produzindo uma informação até então desconhecida: o total de corpos sem estes dados de reinumação. Eles seriam 1942, entre 1410 pessoas sepultadas com seus nomes próprios e 532 como não-identificadas ${ }^{17}$. De forma ambígua, o GTP usa esse total para seus cálculos genéticos, mas suas investigações não se propõem a confirmar ou rejeitar a hipótese sobre a correspondência entre os corpos da vala e as inumações não registradas nos livros, assim como não admitiu tais nomes ao Universo de Busca. Assim fazendo, reafirma a violência de Estado como aquela que se abate sobre a militância, e mantém o reconhecimento reativo às suas demandas.

Sobre essa maioria de corpos que restará não-identificada, pouco se fala até o momento. Sabemos apenas que os profissionais da equipe Ante Mortem os consideram vítimas de outro fenômeno: o desaparecimento administrativo (Hattori et al., 2015). Fruto da economia institucional da identificação no IML, marcada pelo desmazelo e contenção de esforços já descrita por Ferreira (2007), mas esvaziada da violência persecutória que caracteriza o desapa-

17 A diferença entre este número e o total de indivíduos só poderá ser conhecido ao fim do processo. Sabe-se que cerca de 500 ossadas foram excluidas e deixadas no cemitério no momento da exumação. 
recimento político. Esta definição por contraste parece corresponder mais à diferenciação ética e metodológica que anima a equipe e a caracteriza como tecnologia humanitária do cuidado, empenho, padronização, e detalhamento documental, do que responder a diferenças na realidade material dos corpos da Vala de Perus. Ou mesmo na realidade de suas vidas, mortes e razões de desaparecimento, sobre os quais nada sabemos. Ao classificar os corpos entre duas categorias contrativas, o GTP afirma seu poder identificador, tornando-os acessíveis a uma gestão governamental vigilante com as fronteiras que ergue em torno da cidadania.

\section{REMANESCENTES}

Eu não poderia concluir esta reflexão sem mencionar a presença dos desaparecidos políticos no laboratório. No dia a dia, nada chama mais atenção do que o grande mural com suas fotos. Dificilmente se pode perdê-los de vista, enquanto eles parecem ser nossos observadores privilegiados. Há uma clara dinâmica: enquanto os ossos exigem saberes e técnicas, os mortos demandam compromisso. Simbolizando a luta de seus familiares que ali não estão. Essa sensação me veio já no primeiro dia de pesquisa, quando fui solicitada a colaborar com os voluntários na lavagem. Experiência que me exigiu superar receios de mútua contaminação, temendo que os ossos pudessem atuar sobre minha integridade, e eu sobre sua qualidade como objetos científicos. Mas, mais do que isso, sob o olhar congelado dos desaparecidos, era incontornável a sensação solene de manipular um objeto sagrado, cujas propriedades morais eu poderia ferir.

Apontando essa dupla presença, Verdery (1999) alerta sobre como a efetividade simbólica dos mortos reside justamente na concretude manipulável dos corpos que, parecendo encerrar seus próprios significados, se abrem à polissemia. Como objetos apreciáveis pelos sentidos e disponíveis à conveniência dos vivos, a materialidade parece capaz de transcender o tempo, fazendo o passado presente. Contudo, o fato de estar ancorada em biografias e moralidades indica que a relevância de sua materialidade não se encerra sobre si mesma, mas se refere àquela atribuida aos mortos.

Seja manipulando os ossos, seja observando o cotidiano do laboratório, a pesquisa me permitiu perceber como a dimensão simbólica não deixa de ser observada porque a material é objeto científico. Como bem observou Crossland (2009) sobre o fazer arqueológico, ou Fonseca e Garrido (2016) em outro contexto laboratorial, estas duas dimensões não são antagônicas. Ao contrário, o rigor científico pode ser entendido como uma forma de deferência ritual que implica em humanização. Ao traduzir, registrar, ordenar, construir e proteger a integridade dos ossos, o processo científico «mantém a singularidade de histórias individuais. A individualidade documental (...) é o que garante que receberá um tratamento especial» (ibidem: 10). É o que parecem argumentar os membros da equipe Ante Mortem, quando vislumbram a possibilidade dos não-identificados receberem nomes próprios em futuros esforços. Conforme aponta Crossland (2009), o idioma empírico da objetividade aponta a neutralidade como meio ideal de observação e registro das evidências, canalizando uma maneira específica de compreender a relação entre o simbólico e o material. Tal maneira controla a agência atribuida aos "ossos que falam» e o apelo mágico dos mortos que "testemunham» através deles, mas sem superá-los inteiramente. A expectativa de 
continuidade entre o símbolo e o objeto oblitera as relações e processos que se interpõem entre eles para unificá- $\operatorname{los}^{18}$.

A agência atribuída aos ossos objetificados pela técnica seria melhor pensada como elemento que se expressa na complexa rede de relações na qual eles se inserem com as técnicas forenses, o Estado, e o movimento de familiares. Como ato de reconhecimento, identificar significa inscrever verdades públicas sobre uma população assentada em desigualdades, atribuindo significado e lugar social a corpos hierarquizados. Assim, o que o GTP reconhece não é a materialidade em si, mas seus vínculos com atores legitimamente inscritos no jogo político nacional por meio de sua luta por direitos: os familiares de mortos e desaparecidos políticos, que têm os desaparecidos absorvidos em sua substância moral (Bevilaqua, 2010) como uma ausência incorporada (Azevedo, 2018). Porque remanescentes são tanto aquilo que sobra dos mortos, quanto aqueles que a eles sobrevivem.

\section{REFERÊNCIAS BIBLIOGRÁFICAS}

Anstett, E., \& Dreyfus, J.M. (2015). Introduction: why exhume? Why identify? Em E. Anstett \& J.M. Dreyfus (Eds.). Human Remains and identification. Mass violence, genocide, and the "forensic turn» (pp. 1-13). Manchester: Manchester University Press.

Azevedo, D. (2018). Ausências Incorporadas. Etnografia entre Familiares de Mortos e Desaparecidos Políticos no Brasil. São Paulo: Editora Unifesp.

Bevilaqua, C. (2010). Sobre a fabricação contextual de pessoas e coisas: as técnicas jurídicas e o estatuto do ser humano após a morte. Mana, 16(1), 7-29.

Bourdieu, P. (2006). A ilusão biográfica. Em M. Ferreira \& J. Amado (Eds.). Usos e abusos da história oral (pp.183-192). Rio de Janeiro: FGV.

Bourdieu, P. (2011). Razões Práticas: sobre a teoria da ação. Campinas: Papirus.

Butler, J. (2017). Marcos de Guerra. Quando a vida é passivel de luto? Rio de Janeiro: Civilização Brasileira.

Carrara, S. (1984). A «Sciência e Doutrina da Identificação no Brasil» ou do Controle do Eu no Templo da Técnica. Boletim do Museu Nacional, 50, 1-26.

Castillejo Cuéllar, A. (2018). Del ahogado el sombrero, a manera de manifiesto: esbozos para una crítica al discurso transicional. Vibrant, 15(3), 1-16.

Corrêa, M. (2013). As ilusões da liberdade: Nina Rodrigues e a antropologia no Brasil. Rio de Janeiro: Editora Fiocruz.

Crossland, Z. (2009). Acts of estrangement. The post-mortem making of self and other. Archaeological Dialogues, 16(1), 102-125.

18 Como colocam Latour e Woolgar (1997), a percepção de veracidade do fato científico está ligada à peculiaridade de ser produto de um processo de construção que se concretiza como tal na medida em que apaga qualquer traço de si próprio. 
Damatta, R. (1997). Carnavais, Malandros e Heróis. Para uma sociologia do dilema brasileiro. Rio de Janeiro: Zahar Editores.

Das, V., \& Poole, D. (2004). State and its margins. Em Anthropology in the Margins of the State (pp. 3-34). Santa Fe: School of American Research Press.

Douglas, M. (2010). Pureza e Perigo. São Paulo: Ed. Perspectiva.

Dziuban, Z. (2017). Introduction. Forensics in the Expanded Field. Em Z. Dziuban (Ed.). Mapping the 'Forensic Turn'. Engagements with Materialities of Mass Death in Holocaust Studies and Beyond (pp. 7-38). Viena: New Academic Press.

Ferrándiz, F., \& Robben, A. (2015). Introduction: The Ethnography of Exhumations. Em F. Ferrándiz \& A. Robben (Eds.). Necropolitics Mass Graves and Exhumations in the Age of Human Rights (pp. 1-38). Philadelphia: University of Pennsylvania Press.

Ferreira, L. (2007). Dos autos da cova rosa. A identificação de corpos não identificados no Instituto Médico Legal, 1942 a 1960 (Tesis doctoral inédita). Rio de Janeiro: Museu Nacional/ PPGAS.

Fonseca, C., \& Garrido, R. (2016). Os limites do humano: O agency (e complicações) de restos humanos em um laboratório de genética forense. Anais da $30^{a}$ Reunião Brasileira de Antropologia. João Pessoa, 3 a 6 de agosto de 2016.

Foucault, M. (1980). O Nascimento da Clínica. Rio de Janeiro: Editora Forense Universitária.

Foucault, M. (1999). Vigiar e Punir. Nascimento da Prisão. Petrópolis: Vozes.

Foucault, M. (2007). A governamentalidade. Em Microfísica do Poder. Rio de Janeiro: Edições Graal.

Gatti, G. (2017). Prolegómeno. Para un concepto científico de desaparición. En G. Gatti (Ed.). Desapariciones: usos locales, circulaciones globales (pp. 13-32). Bogotá: Siglo del Hombre Editores.

Ginzburg, C. (1989). Sinais: Raízes de um paradigma indiciário. Em Mitos, emblemas e Sinais: Morfologia e história. São Paulo: Companhia das Letras.

Hattori, M. et al. (2015). O caminho burocrático da morte e a máquina de fazer desaparecer: propostas de análise da documentação do Instituto Médico Legal-SP para antropologia forense. São Paulo: Mimeo.

Latour, B., \& Woolgar, S. (1997). A vida de laboratório: a produção dos fatos científicos. Rio de Janeiro: Relume Dumará.

Lefranc, S. (2017). Ejercer el oficio de especialista em justicia transicional. Em G. Gatti (Ed.). Un mundo de víctimas (pp. 231-240). Barcelona: Anthropos Editorial.

Medeiros, F. (2012). «Matar o morto». A construção institucional de mortos no Instituto MédicoLegal do Rio de Janeiro (Tesis doctoral Inédita). ICHF, UFF, Niterói.

Moon, C. (2014). Human rights, human remains: forensic humanitarianism and the human rights of the dead. International Social Science Journal, 65 (march-june), 49-63.

Peirano, M. (2006). A lógica múltipla dos documentos. Em M. Peirano (Ed.). A teoria vivida e outros ensaios de antropología (pp. 135-154). Rio de Janeiro: Jorge Zahar Editor. 
Rosenblatt, A. (2015). Digging for the Disappeared. Forensic Science after Atrocity. Stanford: Stanford University Press.

Stepputat, F. (2014). Introduction. Em F. Stepputat (Ed.). Governing the dead. Sovereignty and the politics of dead bodies (pp. 1-10). Manchester: Manchester University Press.

Torpey, J. (2006). Making whole what has been smashed: on reparation politics. Cambridge, Massachusetts, and London, England: Harvard University Press.

Verdery, K. (1999). The political lives of dead bodies. New York: Columbia University Press.

Wagner, S. (2008). To Know Where He Lies: DNA Technology and the Search for Srebrenica's Missing. Berkeley: University of California Press. 